\title{
IMPACT OF SIGNALLING DEVICE FAILURES IN CONTEXT OF THE RAILWAY TIMETABLE
}

\begin{abstract}
The quality of the transport process in railway transport depends on the compliance of the timetable. Delays in rail transport are due to various reasons. One of the common factors is also failures in the stations or track interlocking systems. In the article is published the results of the performed simulation of failures of interlocking systems in the conditions of the transport laboratory at the Department of Railway Transport. The research was part of a student project solved at the University of Zilina.
\end{abstract}

Keywords: Signalling devices, Train delays, Railway infrastructure

\begin{abstract}
Adam Gajdoš
${ }^{1}$ Faculty of Operation and Economics of Transport and Communications University of Žilina, Univerzitná 8215/1,01026 Žilina; +421/415133434; juraj.camaj@fpedas.uniza.sk

Zitrický Vladislav ${ }^{2}$

${ }^{2}$ Faculty of Operation and Economics of Transport and Communications University of Žilina, Univerzitná 8215/1, 01026 Žilina; +421/41 513 3434; stefan.carny@fpedas.uniza.sk
\end{abstract}

\section{Introduction}

One of the factors influencing the quality of the transport process is the carrier's ability to provide its services reliably - in a guaranteed, pre-announced, or agreed time. In case of deviations from the timetable, resp. agreed transport times in freight transport, the customer's sense of confidence in the carrier's seriousness decreases. Deviations (usually delays) can be classified according to who is responsible for their occurrence (Dedík, 2019). A significant group of delays in rail transport are those caused by the infrastructure manager. These include delays caused by the impact of closures (planned and unplanned), emergencies and accidents, or incorrect transport organisation, but also, for example, individual infrastructure equipment failures (failures regarding switches, traction lines, interlocking devices, etc.). Station and line disruptions, as well as level crossing interlocking devices (ID), are some of the frequent causes of train delays, which adversely affects the train schedule (timetable) fulfilment and, as a result, customer satisfaction with the provided transport services. By analysing the impact of ID failures on the timetable performance and its concretisation, it is possible to obtain new knowledge on the issue of railway transport irregularities, which could be used in the future, for example in operational traffic management. However, this effect cannot be clearly defined or quantified in the stochastic conditions of real railway operation (Lupták, 2017 and Meško, 2017).

Therefore, to assess the impact we simulated railway operation in the transport laboratory of the Department of Railway Transport, Faculty of PEDAS at the University of Žilina in Žilina, and addressed issues with its equipment (various types of station and line signalling systems used in practice) and functions. The experimental measurement was performed in December 2019 and had two phases, each lasting 2 hours, whereby transport on the track was carried out according to a pre-prepared train traffic schedule. Only passenger transport trains were included in the chart, i.e., trains in the express (Ex), fast (R), passenger train (Os) and trains categories. A total of 6 fast trains, 5 express trains, 9 passenger trains and 2 set trains ran during the timetable. Two sets were used for passenger train transport, one set for IC train transport and one set for express train transport, so a total of four sets were used in the chart. The transport was managed according to the usual service regulations and procedures of the Railways of the Slovak Republic (ŽSR).
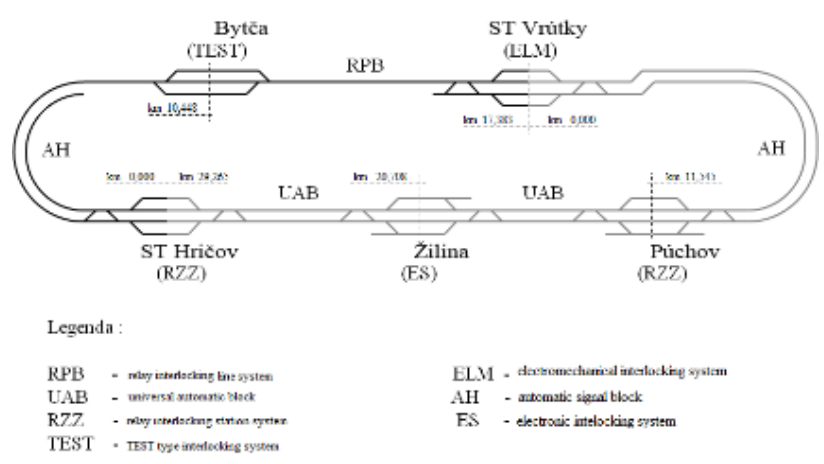

Fig. 1 Track diagram in the KŽD transport laboratory (Gašparík, 2013)

\section{Solving specific issues}

In the first phase, the railway operation was simulated without any emergencies or operational failures. This schedule was met $100 \%$, all trains went on all sections of routes on time. In the second phase of the measurement, we simulated a large-scale station security equipment failure, where it was necessary to completely stop the traffic in the adjacent inter-station sections during the removal. For example, a similar situation occurred in February 2016 at the Bohumín railway station, when due to a fire in several electrical parts of the security 
equipment, traffic through this important transport station was completely stopped for several hours.

In the transport laboratory, we simulated this situation at the Púchov railway station, which is equipped with a relay station interlocking device (SID) with digital dialling. Alternative bus transport (ABT) was introduced in the sections Púchov - Vrútky and Púchov - Žilina. ABT was fictitiously provided by two groups of buses, while one group replaced trains of categories IC and R in the affected section Žilina - Púchov - Vrútky, the other group formed a replacement for Os trains. The number of buses in both groups were different, commensurate with the capacity of the trains. The ABT driving time surcharge was set at 2 minutes for each section. As at the same time with the ABT introduction, the so-called rotation of train sets in Žilina and Vrútky stations, there were also changes in their order - express and express sets were interchanged for trains in these categories in the mentioned stations, because of this both set trains were also abandoned.

Of course, with the introduction of a large alternative bus transport the chart could no longer be met $100 \%$. Due to train delays, operational changes were taken in traffic management, these mainly concerned the train sequence. Ex operational trains had the highest priority in operational management, followed by express trains. The running of regional passenger trains had the lowest priority. Evaluation of train running according to the electronic traffic $\log$ data is the subject of Table 1 .
Table 1. Summary of all trains dispatched in the examined timetable together with an overview of their delays at the point

\begin{tabular}{|c|c|c|c|c|c|}
\hline $\begin{array}{l}\text { Train } \\
\text { number }\end{array}$ & $\begin{array}{l}\text { Cate } \\
\text { gory }\end{array}$ & $\begin{array}{c}\text { Time of } \\
\text { departure } \\
\text { from } \\
\text { starting } \\
\text { station }\end{array}$ & $\begin{array}{l}\text { Initial } \\
\text { train } \\
\text { delay } \\
\text { [min] }\end{array}$ & $\begin{array}{c}\text { Time of } \\
\text { arrival at } \\
\text { the } \\
\text { destination } \\
\text { station }\end{array}$ & $\begin{array}{l}\text { Total } \\
\text { train } \\
\text { delay } \\
\text { [min] }\end{array}$ \\
\hline 501 & Ex & $17: 15$ & 4 & $17: 26$ & 10 \\
\hline 503 & $\mathbf{E x}$ & $17: 28$ & $\mathbf{0}$ & $17: 45$ & 12 \\
\hline 505 & $\mathbf{E x}$ & $17: 46$ & 5 & $18: 02$ & 15 \\
\hline 507 & $\mathbf{E x}$ & $18: 06$ & 6 & $18: 20$ & 16 \\
\hline 509 & $\mathbf{E x}$ & $18: 44$ & 28 & $18: 52$ & 32 \\
\hline 511 & $\mathbf{E x}$ & $18: 54$ & 26 & 19:03 & 30 \\
\hline 600 & $\mathbf{R}$ & $17: 28$ & 10 & $17: 37$ & 14 \\
\hline 602 & $\mathbf{R}$ & $17: 46$ & 12 & $17: 56$ & 18 \\
\hline 604 & $\mathbf{R}$ & $17: 59$ & 12 & $18: 23$ & 21 \\
\hline 606 & $\mathbf{R}$ & $18: 15$ & 5 & $18: 30$ & 15 \\
\hline 608 & $\mathbf{R}$ & $18: 32$ & 0 & $18: 47$ & 10 \\
\hline 1831 & Os & $18: 38$ & 0 & $18: 40$ & 0 \\
\hline 2800 & Os & $17: 12$ & 0 & $17: 32$ & 0 \\
\hline 2801 & Os & $17: 11$ & $\mathbf{0}$ & $17: 32$ & 5 \\
\hline 2802 & Os & $17: 42$ & 2 & $17: 55$ & 3 \\
\hline 2803 & Os & $17: 38$ & 0 & $17: 56$ & 7 \\
\hline 2804 & Os & $17: 59$ & 2 & $18: 18$ & 6 \\
\hline 2805 & Os & $18: 00$ & 0 & $18: 10$ & $\mathbf{0}$ \\
\hline 2806 & Os & $18: 22$ & 0 & $18: 33$ & 0 \\
\hline 2807 & Os & $18: 15$ & 0 & $18: 29$ & 2 \\
\hline
\end{tabular}

Table 1 shows that the average delay of express trains at the destination station was $19.17 \mathrm{~min}$, at speeds of 15.60 min, but in the case of passenger trains only $2.56 \mathrm{~min}$. The total average train delay in the destination RST was 10.80 min. We also evaluated the average arrival delays of arrivals and departures at individual stations. These statistics can be found in Table 2 .

Table 2. Average train delays on arrival and departure from individual transport

\begin{tabular}{|c|c|c|c|}
\hline ŽST & $\begin{array}{c}\text { Average delay } \\
\text { at arrival [min] }\end{array}$ & $\begin{array}{c}\text { Average delay at } \\
\text { departure [min] }\end{array}$ & $\begin{array}{c}\text { Average reduction of } \\
\text { delays at the railway } \\
\text { station [min] }\end{array}$ \\
\hline Púchov & 11.00 & 8.38 & $\mathbf{2 . 6 2}$ \\
\hline Žilina & 9.29 & 8.60 & $\mathbf{0 . 6 9}$ \\
\hline Vrútky & 8.50 & 10.27 & $\mathbf{- 1 . 7 7}$ \\
\hline Hričov & 7.33 & 5.93 & $\mathbf{1 . 4 0}$ \\
\hline Bytča & 8.27 & 8.40 & $\mathbf{- 0 . 1 3}$ \\
\hline
\end{tabular}

Source: Authors 
The absolute fulfilment of the train traffic schedule in the second measurement phase reached only $52.5 \%$ when calculated by the ŽSR methodology. The ŽSR methodology for calculating the absolute performance of the timetable correlates the number of trains going on time (according to the ŽSR methodology, trains going on time are considered to be trains with a delay of no more than 5 minutes) and the total number of departing and ending trains taken over from another regional directorate or network of another infrastructure manager and to another circuit or network of the transferred trains. Therefore, each train is counted twice in this calculation.

Table 3. Calculation of absolute timetable fulfilment using ŽSR methodology

\begin{tabular}{|l|l|}
\hline \multicolumn{2}{|c}{ methodology } \\
\cline { 2 - 2 } Number of trains according to timetable & 20 starting trains \\
\cline { 2 - 3 } $\begin{array}{l}\text { Total number of trains for ŽSR } \\
\text { calculation method }\end{array}$ & $\mathbf{4 0}$ trains \\
\hline Number of trains & 14 starting trains \\
\cline { 2 - 2 } & 7 destination trains \\
\hline $\begin{array}{l}\text { Total number of trains on time for } \\
\text { ŽSR calculation method }\end{array}$ & $\mathbf{2 1 ~ t r a i n s}$ \\
\hline $\begin{array}{l}\text { Absolute performance of timetable } \\
\text { according to the ŽSR methodology }\end{array}$ & $\mathbf{2 1} / \mathbf{4 0}=\mathbf{5 2 . 5} \%$ \\
\hline
\end{tabular}

Source: Authors

When calculating the timetable's relative performance, each train is considered only once - only the terminating trains and trains handed over to the district of another regional directorate or to the railway network of the neighbouring infrastructure manager are used. In this way, only the delay of trains at the end of the journey in the monitored circuit is monitored. The timetable's relative fulfilment in the second phase of the simulation reached $35 \%$ - relatively on time (with a delay of no more than 5 minutes) only seven of the twenty trains arrived at the destination station. It was always a regional train of category Os.

The implemented timetable's analysis provided us with a detailed overview of the course of railway transport during the measurement and pointed out several facts that would occur in a similar operating situation or could occur in real conditions of railway operation. Passenger trains ran mostly on time during the timetable, most delays in this category of trains did not exceed 5 minutes. However, long-distance trains (categories Ex and R) had very high delays. Regional (9 train axes in total) and long-distance trains (11 Ex and R trains in total) had the same conditions - two train sets and one group of ABT buses were deployed on both groups of trains in the section excluded due to a signalling equipment failure. The length of turnovers at the destination train stations was slightly different for regional and long-distance trains in the implemented timetable - for express trains it was $9.80 \mathrm{~min}$ on average, for express trains $13.50 \mathrm{~min}$ and for passenger trains $8.71 \mathrm{~min}$, in total $10.25 \mathrm{~min}$. It turned out that the significant difference between regional and long-distance train delays was caused by the very short running times of long-distance trains. No time reserve in the event of emergencies was considered when constructing their routes. Due to the very short stays at the waypoints, it was not possible to achieve a reduction in train delays during stays; in addition, longdistance trains did not stop at all stations according to the timetable. The deployment of only one group of buses for Ex and $\mathrm{R}$ trains also proved to be insufficient, because during the measurement there were moments when ABT buses as a substitute for a long-distance train were still fictitious in one station or on the road but in another station, which bounded section with ABT, a long-distance train in the opposite direction has already arrived. This train was unnecessarily late.

Statistics regarding average train delays on arrival and departure from individual stations also brought interesting results, whereby the influence of individual types of SID on the overall course of timetable was demonstrated. In the stations Hričov (relay SID with road selection) and Žilina (electronic SID) the reduction of delays was achieved, and to which the double-track operation between these stations also contributed. This section is equipped with an automatic line ID, the so-called autoblock. Reduced delays were also recorded at the Púchov station, which, however, was served only by ABT buses. As it is an operationally important station, where, according to the simulated timetable, trains of all categories stopped and several trains ended and started here, there was room for a more significant reduction of delays even during the ABT introduction. At the Bytča station, equipped with an electric SID of the TEST type, the average train delays on arrival and departure were approximately the same. The reason is probably the nature of the traffic - it is an intermediate station on a single-track line. Therefore, crossings often took place here, during which delays were also passed on to oncoming trains. The Vrútky station is equipped with an electromechanical SID. At present, it is already a morally and technically obsolete type of SID, and at the same time the oldest type of SID represented in the transport laboratory. A shift in stations with electromechanical SID is unsecured - the position of switches and freedom of travel are not controlled by SID. Therefore, the entire course of the shift depends on the station staff, which prolongs its total time. This may be one of the reasons why there was a significant increase in the average train delay at the Vrútky station, where train sets ended and switched to trains in the opposite direction.

The analysis of train traffic during the simulated timetable also revealed the incorrect organisation of the dispatcher's work at the Vrútky railway station at train 509. For this departure train to Púchov via Hričov, a set from train 606 was available here, which arrived in Vrútok at 18:21. After considering the necessary shift and technological tasks at the initial passenger transport train, train 509 was able to leave the station at approximately 18:35 after the arrival of train 2806 from Bytča. However, the dispatcher forgot the Ex 509 train and sent it out of the station after the next train sequence at 18:44. It was a human factor failure, which is one of the most difficult to eliminate, but by its nature significant risks of traffic 
management in the event of unforeseen events in railway operation.

\section{Conclusion}

Based on identifying the weak points in the eliminating the consequences of irregularities in railway traffic, concrete measures can be taken to better address them in the future. One of the basic means for train delay elimination has proven to be the construction of train paths with targeted time reserve inclusion as a tool for reducing delays and covering other irregularities in operation. In order to significantly eliminate delays and limit their transmission to subsequent trains, it is also possible to consider longer turnovers at destination stations. However, when applied in practice, this measure is likely to increase the turnover of vehicles and staff, and therefore a significant increase in operating costs. Therefore, from the carrier's point of view it is more effective to focus on the operational solution of complex operational situations, such as security device failures. For the operative solution of extraordinary events in operation, it is necessary to have enough contractually secured bus carriers and buses themselves, which could be used in the event of extraordinary or accidental events to provide alternative bus transport in the affected section to a reasonable extent and quality. The performed simulation showed that if a third group of buses were available for ABT in the section Žilina - Púchov - Vrútky, would the ABT be better organised (if the capacity of both groups of ABT buses allowed them to be deployed on any long-distance or regional train), the overall train delays could be significantly lower.

Further train delay elimination can be achieved by modernising (especially) station signalling equipment. Modern types of electronic signalling devices significantly shorten the operating intervals (crossing interval, the interval of gradual entrances) in transport stations. The shift in stations equipped with electronic SID is ensured, i.e., is under the control of the station signalling device.

Reducing the impact of emergencies on timetable compliance can also be achieved at the level of human resources. With quality training in the transport emergencies field for employees involved in traffic management, it is possible to increase their ability to deal with emergencies and eliminate their impact on traffic decisively and correctly. For example, training on traffic management simulators is suitable, such as the so-called training halls in the centres of remote-control tracks, whereby employees have the opportunity to practice solving various emergencies. Another possibility is to increase the psychological resilience of transport staff, for example, to stress or fatigue through special psychological courses.

\section{Acknowledgment}

The article was created with the support of the student grant project of UNIZA KOR / 7454/2019 "Influence of security device failures on the fulfilment of the train traffic schedule", that was solved on the University of Zilina.

\section{References}

Dedík, M., Čechovič, T., Gašparík, J., Majerčák, J. 2019. Rationalization of the passenger transport system as an important transport system. Transportation Research Procedia, vol. 40, pp. 193-200, doi:10.1016/j.trpro.2019.07.030

Lupták, V., Gašparík, J., Chovancová, M. 2017. Proposal for evaluating a connection quality within transport networks. MATEC Web of Conferences, vol. 134, doi:10.1051/matecconf/201713400033

Meško, P., Gašparík, J., Lalinská, J. 2017. Railway capacity issues on Slovak international corridors. Transport Means - Proceedings of the International Conference, 2017, pp. 436-441.

Gašparík, J. et al. 2014 Železničná dopravná prevádzka: laboratórny dopravný výcvik. (Railway traffic control:transport laboratory training). $1^{\text {st }}$ ed., Žilina: Žilinská univerzita, 142 p., ISBN 978-80-554-08248. 